\title{
Tunge tap med djupe gåter
}

\author{
Legen kan møte lidingsgåta som eit spørsmål - kvifor? - brått og uventa. Den lidande nøyder meg inn i si pine \\ og gåte. Eg kan ikkje røme. Avkledd for svar står eg andsynes den hjelpelause og trivlar etter meining.
}

Han vart verande stille og lite kravstor. I flokken var han lite synleg, i ordbytet passiv. Magnus hadde lært frå tidlege barneår. Alt var ikkje greitt i barndomsheimen. Foreldra hadde sine vanskar. Magnus valde å vere anonym og snill og ta tapet av ein trygg og sutlaus barndom i det stille.

Det vart godt betalt arbeid. Familieetableringa vart fyrst krona med vakkert hus, så kom det born i heimen. Toåringen vart sjuk, fyrst undersøkt ein morgon, så same ettermiddag. Det hadde då kome små, blå flekker på kroppen. Den raskaste båten på øya fór til byen med veslegut, legen og mor. På barneavdelinga vart alt sett i gong, men på kvelden var guten død. Magnus kom med rutebåten - uvitande, ingen hadde mobiltelefon. På avdelinga vart han møtt med meldinga om at guten var død. Då brast det, han skreik som aldri før. Alle bommar brotna. «Nå må du ta deg saman, du må ikkje skrike slik!» fekk han til svar. Så tagde han, i år.

På veg til arbeidet tok han jamnt snøggbåt. Ein dag kasta eit bølgeslag han opp or stolen. Idet han var på veg ned att, slo baugen opp på ny. Han kom frå hendinga med eit samanfallsbrot i ryggen. Både ortopeden og allmennpraktikaren prøvde bøte på smertene, men fånyttes. Smertene kopla seg til angsten. Stadig nye medisiner vart lagde til. Hans ære og identitet - arbeidet - var tapt. Ekteskapet vart oppløyst. Sjukmeldingane tok ingen ende, oppgåver og fellesskap var borte. Det stod om sjølvbilete, meining og samanheng.

Samtalane med Magnus vart referat frå eit sundslite liv. Angsten som reiv, smerter av alle slag var pinefulle å ta imot. Skulle det ikkje snu nokon gong? Eg hadde lite å fare med, anna enn å ta imot han og vere der, ta del i pinen og plagene. Psykiatrisk sjukepleier hadde me ikkje. Presten tyktest uaktuell.

Mor hadde vore omsorgspersonen heime, ho var helten. Han hadde trong om ei kvinne ved si side. Men det var ikkje lett. Fortida og katastrofane hang fast i livet.

Så får eg telefon frå mor: «Kan du kome og snakke med Magnus? Han ligg til sengs.» Med doktorveska i handa, ein freistnad på å gjere meg i stand til oppdraget, møter eg på troppa og bankar på. Mor opnar. «Rommet er oppe, døra beint fram.» Med tunge steg, anande kva eg kan møte, endar eg ved soveromsdøra og bankar på. Stille.
Eg kjem inn i eit dunkelt soverom, rullegardinene er nede, konturar av ei seng. Stille. Så anar eg eit andlet på puta, dyna ligg som eit lok over senga. Andletet stirer tomt beint i taket. Ingen ord.

Det finst ikkje stol å sitje på. Eg har ikkje kraft til å sitje på sengekanten. I staden set eg meg på golvet med ryggen mot veggen og pustar stille.

«Så sat dei hos han på jorda i sju dagar og sju netter. Ingen sa eit ord til han, for dei såg at hans smerte var stor» (1).

Rommet talar: Sengekassen gjev ly til ein skræmd fugl. Vegger og gardiner fungerer som bolverk og skodder mot den vonde og

\section{«Litteratur frå årtusen attende, heilage skrifter, trivlar etter og strir \\ med svar»}

harde røynda der ute. Pusten hans er knapt høyrbar, han ligg aldeles stille, som utsløkt.

Så kjem eit ord med intens ynk og pine: «Koffår?»

Dette opprivande ordet har stige frå heile jorda, som rop eller klage, med sukk eller ank, frå tragedier, nederlag og framiliedrama, sjukesenger og gravfylgje, frå fangehòl, blodmarker og piggtrådleirar, frå skjelv, flaum og brann.

Kvifor!

Litteratur frå årtusen attende, heilage skrifter, trivlar etter og strir med svar. Religionane snakkar om synd, karma eller lagnad for å få dette til å gå ihop.

Det vrengjer seg i meg: Spør ikkje meg, men heller ein prest, sjaman, imam, filosof eller ateist! Men dei er ikkje her. Eg finn berre ord som er klingande malm, tomt snakk. Eg lyt gje opp.

«Nå set du meg på ei svær prøve, Magnus, eg kan ikkje gje deg noko svar. Når eg endar i slike fortvila stunder, veit eg berre éin veg, eg må be til Gud. Dersom du vil at eg skal prøve svare, må eg spørje deg: Vil du eg skal be?».

«Ja.»
Fyrst det tømande sukket, så bøna: «Du ser oss Gud, to hjelpelause menneske. Magnus har det vondt. Han har mist så mykje. Sjå i nåde til han. Berg han ut or dette mørket.» Medan eg ber, opplever eg ei merkeleg endring. Det er som rommet lysnar, det rislar ei oppleving av fred gjennom kroppen. Den trykkjande atmosfæren vik. Det kjem ingen reaksjon frå Magnus. Eg klarer ikkje snakke til han, men reiser meg, seier takk for meg og går, underleg lett til sinns.

Nokre dagar etter møtte eg mora. Ho kunne fortelje at Magnus hadde vore sengeliggjande fleire dagar før eg kom. Same ettermiddag eg hadde vore der, stod han opp og åt og snakka med dei. Ei heil tid etter trefte eg han.

«Var det eit feilgrep at eg bad for deg?» «Nei, det gjorde godt at du bad. Etter kvart som orda strøymde, kjende eg eit trykk som bygde seg opp inne i brystet. Brystkassen fekk luker som ville sprengjast opp.» Heime hadde han lært, og repetert på sjukehuset, at det gjeld å halde att, ikkje skrike og bere seg, berre tie og lide. Det kunne han. Han lukkast også denne gongen, han heldt att.

Det reiv i meg: «Så sårt, du skulle late stengsla sprengje seg opp, late skrik og pine fosse ut.»

Åra har gått. Magnus bur ein annan stad. No går det han vel, han er nøgd med livet.

Pasienten har samtykt til publisering. «Magnus» er eit fiktivt namn.

\section{Aslak Bråtveit}

aslsigu@online.no

Aslak Bråtveit (f. 1951) er lege ved Finnøy legekontor, Finnøy.

Ingen oppgjevne interessekonfliktar.

\section{Litteratur}

1. Bibelen. Job 2,13.

Motteke 18.9. 2013, første revisjon sendt inn 7.11. 2013, godkjent 16.12. 2013. Redaktør: Are Brean. 